\title{
ANALYSIS OF ADOLESCENT SEXUAL BEHAVIOR IN BOGOR TARUNA TERPADU BORCESS MIDDLE SCHOOL
}

\author{
Resty Jayanti, Ade Saputra Nasution \\ Departement of Public Health, Faculty of Health Sciences, Universitas Ibn Khaldun Bogor
}

\begin{abstract}
Adolescents At This Time Experienced A Very Rapid Social Change From Traditional Society Towards Modern Society, Which In Turn Changed The Values, Norms, Including The Lifestyle Of Adolescents. The occurrence of sexual behavior in adolescents has increased which is influenced by factors from adolescent individuals and factors outside of adolescents themselves. This Study Aims To Analyze The Factors of Sexual Behavior In Adolescents. This study used a cross-sectional approach with a sample of 73 grade VIII students in Bogor Tarcess Integrated Junior High School taken by stratified random sampling, which was analyzed using the chi-square test. The results of this study were measured using a questionnaire that described sexual behavior in adolescents had occurred a lot due to factors within and outside elements of adolescent individuals, where access to information, distance, costs, parental relationships, peer influence has a p-value $<\alpha(0.05)$ which means that there is a relationship with risky sexual behavior in adolescents. Still, the attitude factor shows different results ie, 0.853> a (0.05), which means not related. Parents and Schools need to work together in providing reproductive health education to adolescents to avoid sexual behavior.
\end{abstract}

Keywords: Sexual behavior, teenager

\begin{abstract}
ABSTRAK
Remaja pada masa ini mengalami sebuah perubahan sosial yang sangat cepat dari bentuk masyarakat tradisional kearah masyarakat modern, yang pada akhirnya mengubah nilai-nilai, norma-norma, termasuk gaya hidup remaja. Terjadinya perilaku seksual pada remaja mengalami peningkatan yang dipengaruhi oleh faktor dari individu remaja maupun dari faktor luar remaja itu sendiri. Penelitian ini bertujuan untuk menganalisis perilaku seksual pada remaja dan faktor-faktor yang berhubungan dengan perilaku seksual pada remaja. Penelitian ini menggunakan pendekatan cross sectional dengan sampel sebanyak 73 siswa kelas VIII di SMP Taruna Terpadu Borcess Bogor yang diambil secara stratified random sampling, yang dianalisis menggunakan uji chi-square. Hasil penelitian ini diukur menggunakan kuesioner yang menggambarkan perilaku seksual pada remaja sudah banyak terjadi yang dikarenakan oleh faktor dalam diri maupun faktor dari luar individu remaja, dimana akses informasi, jarak, biaya, hubungan orangtua, pengaruh teman sebaya memiliki p-value $<\alpha(0,05)$ yang artinya ada hubungan dengan perilaku seksual berisiko pada remaja, namun faktor sikap menunjukkan hasil yang berbeda yaitu $0,853>\alpha(0,05)$ yang artinya tidak berhubungan. Orang tua dan Sekolah perlu bekerja sama dalam memberikan pendidikan kesehatan reproduksi kepada remaja untuk menghidari perilaku seksual.
\end{abstract}

Kata kunci: Perilaku seksual, remaja 


\section{INTRODUCTION}

Adolescence is a transition from childhood to adulthood, wherein adolescence is categorized as the most crisis period for development in the next life process. In adolescence, now experiencing differences in life challenges compared to several decades before, both in the field of health, social, economic and religion that can affect adolescent behavior. This has an impact on the increase in cases of promiscuity in adolescents resulting in cases of complications of pregnancy, sexually transmitted infections, abortion, psychological disorders and pregnancy in adolescence. ${ }^{1,2}$

Adolescents at this time have not been selective in the influence of information because there is still a lack of knowledge about free sex and personality that is still unstable so that it encourages adolescents to try new things including in sexual relations without considering the impact. This impulse is also the result of the development of biological organs that are starting to mature. ${ }^{3,4}$

The development that occurs in adolescent biological organs, especially the visibility of the protrusion and functioning of the sexual organs and attracts the interest of adolescents to find out more related to perceived changes. Adolescence experiences the process of reproductive hormone production that affects the reproductive cycle so that changes occur and there is a sense of attraction to the opposite sex, and hormonal changes naturally encourage the desire to have sex. ${ }^{5,6}$

Sexual behavior committed by adolescents is also influenced by the social environment, because the time spent with peers is more than that of families which results in decreased interaction with parents, but relationships with peers increase. The environment of friendship is very closely related to interests, attitudes, appearance, speech, and behavior. The existence of a negative influence on social interactions friendships will have an impact on deviant behavior such as juvenile delinquency or free sex. ${ }^{7}$

Parents have a role in helping adolescents in growing self-confidence and enhancing the ability of adolescents in making decisions, to avoid the bad influence of peers. ${ }^{3}$ Parents have to monitor the development and growth of adolescents to avoid deviant behavior. However, lack of attention and supervision by parents can have an impact on promiscuity and the ease of sexual stimulation from mass media, facilities such as computers, the internet, cellphones, social media such as Instagram, Facebook or Twitter and television which have negative effects, where adolescence want to imitate an idol like dating. Dating can be interpreted as a learning process in sexual activity in the opposite sex, which starts from kissing, oral sex, mutual masturbation, even sexual intercourse. ${ }^{8-10}$

Other things that affect sexual behavior in adolescents are belief or religion, gender, ethnicity, distance, cost, place, puberty, knowledge or attitude, self-regulation, self-efficacy, self- 
belief, self-esteem, and religiosity. ${ }^{11,12}$ This study aims to determine the factors that influence the sexual behavior of adolescent Bogor Taruna Terpadu Borcess Middle School.

\section{METHOD}

This study used a cross-sectional approach with a sample of 73 grade VIII students at Bogor Taruna Terpadu Borcess Middle School taken by stratified random sampling and the results were analyzed using the chi-square test. In this study, to measure adolescent sexual behavior than seen from the indicators of the independent variables are knowledge, attitudes, entertainment fee, distance, family relationships, the influence of friends and questionnaires as a measurement tool.

\section{RESULT}

The results section describes the analysis of bivariate and multivariate analysis which are presented in tabular form, and the interpretation of research results was made in narrative form.

\section{Bivariate Analysis}

Table 2. Relationship between attitude and sexual behavior of Bogor Taruna Terpadu Borcess Middle School Student

\begin{tabular}{|c|c|c|c|c|c|c|c|c|}
\hline \multirow{3}{*}{ Factors } & \multicolumn{4}{|c|}{ Sexual Behavior } & \multirow{2}{*}{\multicolumn{2}{|c|}{ Total }} & \multirow{3}{*}{ p-value } & \multirow{3}{*}{$\begin{array}{c}\text { OR } \\
\text { CI 95\% }\end{array}$} \\
\hline & \multicolumn{2}{|c|}{ Take effect } & \multicolumn{2}{|c|}{ No effect } & & & & \\
\hline & $\mathbf{n}$ & $\%$ & $\mathbf{n}$ & $\%$ & $\mathbf{N}$ & $\%$ & & \\
\hline Knowledge & & & & & & & \multirow{3}{*}{0,017} & \\
\hline Less & 61 & $73,0 \%$ & 30 & $33,0 \%$ & 91 & 100,0 & & 2,280 \\
\hline Good & 33 & $47,1 \%$ & 37 & $52,9 \%$ & 70 & 100,0 & & $1,576-4,323$ \\
\hline \multicolumn{9}{|l|}{ Attitude } \\
\hline Positive & 48 & $55,8 \%$ & 38 & $44,2 \%$ & 86 & 100,0 & \multirow{2}{*}{0,583} & 0,647 \\
\hline Negative & 46 & $61,3 \%$ & 29 & $38,7 \%$ & 75 & 100,0 & & $0,104-1,115$ \\
\hline \multicolumn{9}{|l|}{ Information access } \\
\hline Exposed & 61 & $72,7 \%$ & 23 & $27,4 \%$ & 84 & 100,0 & \multirow{2}{*}{0,000} & 3,536 \\
\hline Under-exposed & 33 & $42,9 \%$ & 44 & $57,1 \%$ & 77 & 100,0 & & $1,468-7,629$ \\
\hline \multicolumn{9}{|l|}{ Entertainment Fee } \\
\hline Cheap & 62 & $74,7 \%$ & 21 & $25,3 \%$ & 83 & 100,0 & \multirow{2}{*}{0,000} & \\
\hline Expensive & 32 & $41,0 \%$ & 46 & $59,0 \%$ & 78 & 100,0 & & $1,675-8,523$ \\
\hline \multicolumn{9}{|l|}{ Distance } \\
\hline Near & 63 & $70,8 \%$ & 26 & $29,2 \%$ & 89 & 100,0 & \multirow{2}{*}{0,000} & 3,205 \\
\hline Far & 31 & $43,1 \%$ & 41 & $56,9 \%$ & 72 & 100,0 & & $1,323-7,567$ \\
\hline \multicolumn{9}{|l|}{ Family Relationship } \\
\hline Not good & 61 & $69,3 \%$ & 27 & $30,7 \%$ & 88 & 100,0 & \multirow{2}{*}{0,003} & 2,738 \\
\hline Good & 33 & $45,2 \%$ & 40 & $54,8 \%$ & 73 & 100,0 & & $1,643-4,754$ \\
\hline \multicolumn{9}{|l|}{ Friends Influence } \\
\hline Yes & 67 & $69,1 \%$ & 30 & $30,9 \%$ & 97 & 100,0 & \multirow{2}{*}{0,001} & 3,060 \\
\hline No & 27 & $42,2 \%$ & 37 & $57,8 \%$ & 64 & 100,0 & & $1,896-7,026$ \\
\hline
\end{tabular}

The results of data analysis obtained the value of $\mathrm{P}$-value $0.017<0.05$ means that there is a significant relationship between knowledge and sexual behavior of adolescents. The magnitude of the risk can be seen from the OR value of 2.280 , which means that the condition of adolescent 
knowledge that is lacking will increase the influence of sexual behavior by 2,280 times more influential than in adolescents who have a good understanding.

The results of data analysis obtained P-value 0.583>0.05 which means there is no meaningful relationship between attitudes towards adolescent sexual behavior. The magnitude of the risk can be seen from the OR value of 0.647 , which means that a positive attitude of adolescents will increase the influence of sexual behavior by 0.647 times more influential than adolescents who have negative attitudes.

The analysis results obtained P-value $0,000<0.05$ which means there is a significant relationship between access to information with adolescent sexual behavior. The magnitude of the risk can be seen from the OR value of 3.536, meaning that adolescents who get access to information will increase the influence of sexual behavior by 0.647 times more influential than adolescents who do not get access to information.

Data analysis obtained P-value $0,000<0.05$ means there is a significant relationship between the affordability of costs with adolescent sexual behavior. The magnitude of the risk can be seen from the OR value of 4.244, which means that adolescents who can reach entertainment costs will increase the influence of sexual behavior by 4.244 times more influential than adolescents who cannot reach entertainment venues because of the high prices.

The analysis results obtained P-value of $0,000<0.05$ means that there is a significant relationship between distance affordability with adolescent sexual behavior. The magnitude of the risk can be seen from the OR value of 3.205 , which means that adolescents who have a short distance to the place of entertainment will increase the influence of sexual behavior by 3.205 times more influential than adolescents who are distance away from the site of entertainment.

Analysis of the data obtained P-value $0.003<0.05$ means there is a significant relationship between the influence of family with adolescent sexual behavior. The magnitude of the risk can be seen from the OR value of 2.738 , which means that adolescents who have bad family relationships will increase the influence of sexual behavior by 2.738 times more influential than adolescents who have good relationships with family.

The results of data analysis obtained P-value $0.001<0.05$ means that there is a significant relationship between the influence of friends with adolescent sexual behavior. The magnitude of risk can be seen from the OR value of 3.060, meaning that adolescents who get the influence of friends will increase the influence of sexual behavior by 3.060 times more influential than adolescents who do not get the influence of friends.

\section{DISCUSSION}

The knowledge factor shows the proportion of risky sexual behavior in students who have less knowledge of $73.0 \%$, higher than students who have good knowledge of $47.1 \%$. The view of 
premarital sexual behavior of adolescents who are at risk is influenced by knowledge because knowledge is a domain that can shape a person's behavior. ${ }^{13}$ Teenage knowledge that is wrong about sexuality can make teens conduct experiments about sex without knowing the risks that arise. Behavior that is based on knowledge, in general, is more durable than that which is not based on knowledge. The low knowledge of adolescents about sex is due to the lack of information obtained by adolescents about sex. This makes adolescence find information about sexuality from various mass media. ${ }^{14}$ However, the information obtained from the mass media is incomplete, misleading and dangerous. Lack of knowledge about sexuality can encourage adolescents to try to have premarital sex and misperceptions about sexuality. ${ }^{1,15}$

Adolescent knowledge about reproductive health needs to be provided from appropriate sources, so that it can provide a strong foundation for adolescents in responding to behavior related to sexuality and make adolescents have responsible and healthy sexual attitudes and attitudes. ${ }^{13}$

The attitude factor shows the proportion of risky sexual behavior in students with negative attitudes of $61.3 \%$, higher than students with positive attitudes of $55.8 \%$. Attitude is a perception of a knowledge that is formed negatively or positively that can shape individual behavior. Attitudes are influenced by factors in the mass media, educational institutions, personal experiences, culture, external and emotional influences. Every teenager has different attitudes towards sexual behavior. Attitude is one of the factors that influence the formation of an intention to carry out sexual activity. ${ }^{14,16}$

However, the results of the study stated there was no relationship between attitude and sexual behavior, and this is due to other factors that cause teens who have positive attitudes towards sexual behavior but engage in sexual behavior due to encouragement or coercion from peers, access to information and dating behavior to do the handle hands, kisses, intercourse resulting in the desire of adolescents to engage in premarital sexual behavior.

Mass media (electronic or print), health workers, parents, friends, and teachers are sources of information about sexuality. Mass media that presents pornography has a very large impact that affects sexual behavior. ${ }^{17}$ Adolescence who watch, see and read pornography can stimulate and motivate to practice or imitate. If adolescents are exposed continuously to pornography, it is possible to have premarital sexual relations. ${ }^{12,18}$

The information access factor shows the proportion of sexual behavior at risk of students exposed to access to information about sex by $72.7 \%$, higher than students who are less exposed to access to information about sex by $42.9 \%$. So that adolescents with risky premarital sexual behavior are more likely to be found in students who are exposed to sexual information.

The cost of entertainment factor illustrates the proportion of risky sexual behavior of students who think the cost of cheap entertainment is $74.7 \%$, higher than students who think the cost of expensive entertainment is $41.0 \%$. The results of this study are in line with research 
conducted by Winahyu, which concludes that low-cost entertainment has a risk for adolescents for premarital sexual transactions, and this will affect the frequency or intensity of acts of sexual transactions. From this, that the cheaper or affordable the cost of entertainment venues for sexual transactions, the greater the chance for adolescents to engage in sexual behavior. ${ }^{19}$

The distance factor shows the proportion of sexual behavior at risk of students who get a distance of close entertainment places by $70.8 \%$, higher than students who think the distance of entertainment places is $43.1 \%$. The results of this study are in line with research conducted by Winahyu, who concluded that the distance to close entertainment venues poses a risk to adolescents for premarital sexual transactions, and this will affect the frequency or intensity of acts of sexual transactions. From this, the closer or within reach of sexual entertainment transactions or places, the greater the risk of adolescents to engage in sexual behavior. ${ }^{19}$

Family relationship factors show the proportion of risky sexual behavior of students with unfavorable family relationships in providing supervision and understanding of sexual behavior by $69.3 \%$, higher than students with good family relationships by $45.2 \%$. Adolescent behavior, one of which is influenced by relationships with family, where good relationships with the family will make teens have good sexual behavior. However, some adolescent has a bad relationship with the family who tend to behave riskily sexually. This illustrates that the relationship with the family is still needed, lack of communication between children and parents openly in sexual problems can strengthen the emergence of deviant sexual behavior in adolescents. ${ }^{20,21}$

The family has a role in increasing adolescent understanding specifically and generally about adolescent reproductive health because parents are the earliest and most intensive teen relationships that occur between relationships with humans. ${ }^{22}$ If parents can communicate about sexual behavior with adolescents, then adolescent sexual behavior can control according to the knowledge informed by their parents. ${ }^{23}$ Conversely, if there is no communication about sex education between parents and adolescents, it can lead to risky sexual behavior. ${ }^{24,25}$

Peer factor shows the proportion of risky sexual behavior of students who are influenced by friends by $69.1 \%$, higher than students who are not affected by peers by $42.2 \%$. One of the developments of adolescents is determined by the role of peers, because of the tendency of adolescents to choose friends who have the same values and interests, so that teens feel comfortable to communicate, mutual understanding, mutual trust and openness about adolescent problems that are not communicated to parents. During adolescence, there is also a process of finding or forming identity and copying existing behavior around the environment and this will have an impact on the daily lives of adolescents. ${ }^{26,27}$

Referring to the results of the study, peers have a role in sexual behavior due to the exchange of information about sexuality, frequent discussions and the presence of peers who have 
had premarital sexual relations with both girlfriends and non-boyfriends, so this is used as a benchmark for adolescents in acting and taking a role. Decision.

\section{CONCLUSION}

Knowledge, distance, access to information, peer influence, family relationships, entertainment costs affect sexual behavior in adolescents, but the attitude factor shows no relationship with adolescent sexual behavior.

From the results of this study, it can be suggested to parents to pay more attention, educate or provide reproductive health education to adolescents so that adolescent behavior can be directed to positive things and the school can provide reproductive health information to guide adolescents in the formation of better self-character.

\section{REFERENCES}

1. Nia WW, Pujiati. Faktor-Faktor Yang Mempengaruhi Perilaku Seks Pranikah Remaja Kelas X Dan Xi Di Sma X Kota Depok. Artik Ilmu Kesehat. 2016;8(1):31-6.

2. Dharmawan AA, Qariati NI, Asrinawaty. Analisis Pengaruh Lokalisasi Dan Peran Keluarga Dengan Perilaku Seks Pranikah Pada Remaja. J Ilm Ilmu Kesehat. 2019;5(1):18-22.

3. Bandura A. Social cognitif theory in: Lange PAM, Kruglanski AW, Higgins E, eds. Handbook of theories of social psychology. London: Sage Publisher; 2011. 349 hal.

4. Yuni R, Adi U, Agus W, Mohammad H. Perilaku seks pranikah remaja. J Kesmas Masy Nas. 2012;7(4):180-5.

5. Pramono JS, Dewi A, Auliatunida Z. Pengaruh Teman Sebaya Terhadap Perilaku Seksual Pada Remaja Di Sma Negeri 8 Samarinda Tahun 2010. J Husada Mahakam. 2011;3(2):45-94.

6. Haryani DS, Wahyuningsih, Haryani K. Peran Orang Tua Berhubungan Dengan Perilaku Seksual Pra Nikah Remaja Di SMKN 1 Sedayu. J Ners Midwifery Indones. 2015;3(3):140-4.

7. Sigalingging G, Sianturi IA. Hubungan Teman Sebaya Dengan Perilaku Seksual Remaja Di Smk Medan Area Medan Sunggal. J Darma Agung Husada. 2019;5(1):9-15.

8. Ayodele O, Omolayo O, Bose A. Prevalence of premarital sex and factors influencing it among students in a private tertiary institution in Nigeria. Int J Psychol Couns. 2012;4(1):6-9.

9. Morris J, Young M, Jones. Self-Esteem and Adolescent Sexual Behavior Among Students at an Elite Bolivian School. Int Electron J. 2010;

10. Winarni. Faktor Personal Dan Perilaku Seksual Pranikah Remaja. INFOKES. 2018;8(2):80-5.

11. Rosdarni, Dasuki D, Waluyo SD. Pengaruh Faktor Personal terhadap Perilaku Seksual Pranikah pada Remaja. Kesmas: Jurnal Kesehatan Masyarakat Nasional. J Kesehat Masy Nas. 2015;9(3):214-21. 
12. Mahmudah, Yaunin Y, Lestari Y. Faktor-Faktor yang Berhubungan dengan Perilaku Seksual Remaja di Kota PadangFaktor-Faktor yang Berhubungan dengan Perilaku Seksual Remaja di Kota Padang. J Kesehat Andalas. 2016;5(2):448-55.

13. Wulandari T, Arizona MT, Tambun R, Wahab A. Hubungan Pengetahuan, Sikap, Dan Tindakan Ibu Dengan Status Gizi Anak Balita Di Kelurahan Sei Kera Hilir Ii Kecamatan Medan Perjuangan. J Kebidanan Kestra. 2019;2(1):9-17.

14. Lestari IA. Faktor-faktor yang berhubungan dengan perilaku seks pranikah pada mahasiswa unnes. Unnes J Public Heal. 2014;3(4):27-38.

15. Lisnawati, Lestari NS. Faktor-Faktor Yang Berhubungan Dengan Perilaku Seksual Remaja Di Cirebon. J Care. 2015;3(1):1-8.

16. Solehati T, Rahmat A, Kosasih CE. Hubungan Media Dengan Sikap Dan Perilaku Triad Kesehatan Reproduksi Remaja. J Penelit Komun. 2019;23(1):40-53.

17. Zainafree I. Perilaku Seksual Dan Implikasinya Terhadap Kebutuhan Layanan Kesehatan Reproduksi Remaja Di Lingkungan Kampus (Studi Kasus Pada Mahasiswa Universitas Negeri Semarang. UNNES J Public Heal. 2015;4(3):1-7.

18. Samino. Analisis perilaku sex remaja SMAN 14 Bandar Lampung. J Dunia Kesmas. 2012;1(4).

19. Winahyu L, Husodo BT, Indraswari R. Faktor-Faktor Yang Berhubungan Dengan Perilaku Seksual Berisiko Pada Trucker Di Pelabuhan Tanjung Emas Semarang. J Kesehat Masy. 2016;4(5):330-8.

20. Rokhmah D. Pola Asuh Dan Pembentukan Perilaku Seksual Berisiko Terhadap Hiv/Aids Pada Waria. KEMAS. 2015;11(1):125-34.

21. Ulfah M. Faktor-Faktor Yang Mempengaruhi Perilaku Seksual Pranikah Pada Remaja Smp Dan Sma Di Wilayah Eks- Kota Administratip Cilacap. Medisains J Ilm Ilmu-Ilmu Kesehat. 2018;16(3):137-42.

22. Zefanya M. Faktor Yang Berhubungan Dengan Praktik Seks Pranikah DiKalangan Anak Jalanan Kota Semarang Tahun 2016. J Kesehat Masy. 2016;4(3):1029-35.

23. Gustina E. Komunikasi Orangtua-Remaja Dan Pendidikan Orangtua Dengan Perilaku Seksual Berisiko Pada Remaja. UNNES J Public Heal. 2017;6(2):131-6.

24. Azinar M. Perilaku Seksual Pranikah Berisiko Terhadap Kehamilan Tidak Diinginkan. KEMAS. 2013;8(2):153-60.

25. Runtuwene DR, Ardiansa A. T, Grace E. Hubungan Antara Peran Keluarga Dan Teman Sebaya Dengan Perilaku Seksual Pranikah Pada Siswa Di Sma Negeri 3 Manado. J KESMAS. 2019;8(6):225-31.

26. Putri S, Shaluhiyah Z, Prabamurti PN. Faktor - Faktor Yang Berhubungan Dengan Perilaku Seksual Remaja Yang Tinggal Di Lingkungan Resosialisasi Argorejo Kota Semarang. J 
Kesehat Masy. 2017;5(5):1092-101.

27. Yudia SM, Cahyo K, Kusumawati A. Perilaku Seksual Pranikah Pada Mahasiswa Kost (Studi Kasus Pada Perguruan Tinggi “X” Di Wilayah Jakarta Barat. J Kesehat Masy. 2018;6(1):819_ 25 . 